\title{
Young People, Political Participation and Trust in Britain
}

\author{
BY MATT HENN AND NICK FOARD
}

\author{
Parliamentary Affairs, Vol. 65 (1) pp. 47-67, 2012. \\ DOI: $10.1093 / \mathrm{pa} / \mathrm{gsr046}$. ISSN 0031-2290.
}

\begin{abstract}
Young people in Britain are often characterised as disconnected from the formal political process and from democratic institutions. Certainly their rate of abstention in general election contests over the last decade has led to concerns amongst the political classes that they have a disaffection from politics that is deeply entrenched and more so than was the case with previous youth generations, and may in the future become habit-forming. In this article, we consider the results from an online national survey of 1,025 British 18 year olds conducted in 2011, and compare these with the results from a similar study conducted by one of the authors in 2002. In doing so, our aim is to assess the extent to which young people's levels of political engagement have changed over the course of the intervening years, and if so, how they have changed. The results from this comparison indicate that, contrary to popular wisdom, today's generation of young people are interested in political affairs, and they are keen to play a more active role in the political process. However, their recent experience of their first general election in 2010 has left them feeling frustrated. Indeed, our study has revealed a considerable aversion to formal, professional politics which is as deep today as it was for the predecessor 2002 youth cohort.
\end{abstract}

Over the past decade, there has been growing anxiety within government circles that people in Britain are becoming increasingly disengaged from the formal political process and from democratic institutions (Ministry of Justice, 2007). This concern has come to the fore largely as a consequence of the recent decline in voter participation rates. For instance, election turnout has taken a steep turn downwards, most notably at the landmark General Election of 2001 when only $59 \%$ of the eligible electorate voted. Although voter turnout at subsequent general elections has increased marginally to $61 \%$ in 2005 , and then to $65 \%$ in 2010 , these figures should be put into context by comparing them with previous general election outcomes where electoral participation was 75\% in 1987, 78\% in 1992, and 71\% in 1997 (Electoral Commission, 2005). 
Young people in Britain are even less likely to participate in elections than are their older contemporaries. In support of an apparent generational turnout gap, Franklin (2004) has conducted an extensive international analysis of electoral trends and concluded that age in Britain as in many other countries is a significant predictor of turnout. Certainly, only $39 \%$ of eligible 18 to 24 year olds voted at the General Election in 2001, falling further to 37\% in 2005 (Electoral Commission, 2005). Turnout within this group increased to 44\% in 2010 (Ipsos MORI, 2010), and this small shift upwards in youth voting may reflect the different context of that particular contest which had an appeal that was markedly different to previous general elections. Topics that young people could relate to had largely been discussed on the periphery in previous election campaigns, but in 2010 university tuition fees formed a key campaign issue, and in doing so provided something with which young people could differentiate the political parties. This choice was likely compounded by the fact that first time voters, who had only known a Labour government for most of their living memory, were being told by the polls that a real opportunity to instigate change was presenting itself. However, the youth turnout in 2010 remains well below the national average, and suggests that a large majority of those young people who registered to vote opted not to do so. ${ }^{1}$ It is also a significantly lower turnout rate than estimated in earlier elections, when it was reported as 66\% in 1987 (Swaddle and Heath, 1992), 61\% in 1992 (Butler and Kavanagh, 1997), and 68\% in 1997 (Jowell and Park, 1998).

It is not just in terms of election turnout that young people are differentiated from older contemporaries. The principal theme to emerge out of the existing research into the general field of young people and politics is that this generation has been characterised as dissatisfied with, and alienated from, the political process (Henn et al., 2005; Kimberlee, 2002; Wattenburg, 2002). Furthermore, many studies conclude that young people have comparatively lower-levels of political knowledge than their older contemporaries (Pattie et al., 2004), and have a distinct lack of interest in (formal) politics (Park, 2004). Compared with older adults, they are less likely to be politically active (The Electoral Commission and The Hansard Society, 2007), display comparatively weaker commitments to political parties (Clarke et al., 2004; Tilley, 2003), and are less likely to be members of such organisations (Whiteley and Seyd, 2002; Sloam, 2007). Indeed, the message from many such studies is that young people's levels of political participation in general are in decline, and at a somewhat more rapid rate than is the case for older adults and also for previous youth cohorts (Russell et al., 2002). Moreover, young people have been differentiated from wider society in terms of their political views - they are considered to be less conservative than older contemporaries, highly disillusioned with the operation of politics, and more sceptical of politicians (Henn et al., 2005; Pattie et al., 2004). Furthermore, there is evidence that young people's disengagement from politics is more pronounced than it was for previous youth cohorts (Park, 1995; Kimberlee, 2002).

By way of contrast, a number of recent studies have suggested that whilst young people may have little interest in formal politics, this does not signal a disengagement from all forms of politics, per se. Instead, research indicates that this group do take part in differing forms of

\footnotetext{
${ }^{1}$ Given that data suggest that many young people do not register to vote in the first place (Russell et al., 2002), this figure probably over-estimates the actual turnout rate for young people.
} 
political action (Quintelier, 2007). Research conducted by Norris (2003) indicates that young people are more likely to engage in 'cause-oriented' styles of politics (or what Pattie et al., [2004] refer to as 'micro-politics') than they are in 'formal' politics - participation that uses less institutionalised methods such as demonstrations, boycotts, and direct action. This generation has also taken part in localised social action activities at a higher than average rate without regarding this action as necessarily 'political'. Such activities include volunteering, informal community networks, informal political action, awareness-raising, altruistic acts, and general campaigning (Roker and Eden, 2002). Research by Matthews (2001) also highlights the increased involvement of young people in Youth Councils and Youth Forums - participation which further challenges the notion that young people are politically apathetic. This shift in the way young people are engaging in political activity is increasingly facilitated by access to new media and technologies. Loader (2007) suggests that a 'cultural displacement' is occurring in which young people's identities and forms of expression have shifted from traditional channels to those available through a new media culture; young people are having their political identity shaped by television, blogs and other websites, while actively expressing it through participatory new technologies, such as joining online single issue groups, signing online petitions, and engaging in digital media production such as creating YouTube videos (Bennett, 2008). The televised leadership debates also opened up a channel through which young people conventionally access information, for the first time in a British election. Wring and Ward (2010) suggest that while the televised debates had little impact on voting behaviour, they did help to make viewers better informed.

Despite such evidence of their engagement in different types of political action, the central preoccupation with young people's falling election turnout rates persists. This recent pattern of youth abstention from the polls has helped to create a sense of unease amongst politicians and officials that young people in particular have a disaffection from politics that is deeply entrenched and may become habit-forming; that in the medium- to long-term, the more civic-oriented older generations will be replaced by this younger sceptical and election-boycotting generation (Electoral Commission and the Hansard Society, 2006). The implication, should this happen, is that the legitimacy of representative democracy in Britain would be called into question if large numbers of people continued to abstain at general elections in the future.

The responses of recent UK governments have been to legislate a programme of political reforms designed to reconnect the electorate - and young people in particular - to the political system (Henn and Weinstein, 2006). This has included for instance the introduction of statutory citizenship classes at schools in England in 2002, to educate young people in the nature and practices of democratic participation. Elsewhere, constitutional programmes of change have been introduced that were designed to give citizens greater access to the centres of political power and increased influence over the political process. Governments have also sought to modernise the electoral system and processes with the ambition to make the act of voting easier, and to stimulate turnout at elections.

Despite such measures, the downward trend in democratic engagement has not been arrested to any great extent. Consequently, the Government acknowledged in its 2007 Green Paper, The Governance of Britain, that "power remains too centralised and too concentrated in government... 
(and that) some people have become cynical about, and increasingly disengaged from, the political process" (Ministry of Justice 2007, p.10). As an indicator of this, non-turnout of British youth at recent general elections continues to remain at levels significantly lower than was the case during the 1980s and the 1990s.

\section{Aims and objectives}

In this paper, we intend to consider the notion that young people are disengaged from the formal political process and from democratic institutions. We do this by examining young people's political participation in Britain, and in particular the ways in which formal politics has been viewed by this youth group over the course of two parliaments. We do this by comparing data from a study conducted by the authors in 2011 with data collected by one of the authors a decade earlier (see Henn and Weinstein, 2003). This will enable a comparison to be made with the results from the original study, to assess whether or not the pattern of young people's levels of political engagement have changed in the intervening years, and if so, how have they changed. Specifically we shall address the following issues: young people's levels of interest in, and understanding of, politics and elections; youth attitudes towards democracy in Britain; the degree of trust that young people have in political parties, politicians and democratic institutions; the likelihood that young people will take part in differing political activities in the future, including voting at elections; what the political parties need to do if they are to engage young people in the future.

\section{Research design}

In order to examine these areas, we conducted a national online survey of 1,025 attainers ( 18 year olds eligible to vote for the first-time). The survey was designed to yield a representative national sample of young people from across England, Scotland and Wales, with respondents drawn from an existing and on-going online access panel. ${ }^{2}$ Prior to analysis, the data were weighted to accurately reflect population estimates of gender, ethnicity and region. Given the focus of our research on this very specific age cohort, telephone interviewing using random digit dialling was deemed to be impractical, as this method would result in a large number of unsuccessful calls to households in which suitable respondents did not reside. By the same token, using general household sampling frames such as the postcode address file would have yielded a similarly large number of unsuccessful approaches. The topic of our research also made the electoral register an unsuitable sampling frame, as our study required us to include capture of any young people who were not registered to vote.

Conversely, the benefit of using a pre-existing panel to this particular study is that it enabled us to produce a sampling frame based on our specific cohort, since date of birth is one of a number of variables already known for each panel member. A sub-section of the panel was identified using the criteria that respondents should have had their eighteenth birthday (and therefore be eligible to vote) before the General Election of $6^{\text {th }}$ May 2010, but after the local and European elections of $4^{\text {th }}$ June 2009 . This ensured that all members of our sampling frame had no voting

\footnotetext{
2 This online access panel is co-ordinated by the international market research agency, Ipsos-MORI (http://www.ipsos-mori.com)
} 
experience prior to the 2010 General Election, and it was from this that a sample of attainers was generated.

Early concerns regarding the coverage error inherent in online surveys resulting from limited Internet access, have been well documented (Hewson et al., 2002; Couper, 2000), while more recently, as Internet adoption has become more prevalent, online surveys have been demonstrated to be representative (Chang and Krosnick, 2009). Moreover, Internet access and usage rates of the cohort of interest in our study differ substantially to those of the general population; in 2010, the Office of National Statistics estimated that $99 \%$ of $16-24$ year olds had used the Internet (Office for National Statistics, 2010). Additionally, Ipsos-MORI make use of a combination of online and offline recruitment methods. This mixture of recruitment techniques helps to ensure that, while the data collection takes place online, the sample is not generated exclusively from regular Internet users; this approach was designed to militate against any sampling bias that might have derived from an exclusively online sample selection method.

The questionnaire was designed to enable close comparison to the study conducted by one of the authors in 2002 (see Henn and Weinstein, 2003 ${ }^{3}$ ), and the majority of questions from the previous questionnaire have been repeated. Following consultation with representatives from political parties and interested youth-oriented user groups, a small number of additional questions were included to allow for the exploration of specific issues which have come to the fore since the previous study. Data collection took place from $20^{\text {th }}$ April to $4^{\text {th }}$ May 2011 , thereby ensuring that respondents had not yet had the opportunity to vote in the AV referendum of $5^{\text {th }}$ May 2011.

\section{RESULTS}

\section{Political Engagement}

Our research reveals evidence that, far from being apolitical and apathetic, young people are interested in political matters, and are more so than were their predecessors in 2002 . When asked about politics in general, $63 \%$ of respondents replied that they had some or more interest in the topic, which compares with $56 \%$ expressing such an interest in 2002 . Only $12 \%$ of our survey participants reported that they had none at all (13\% in 2002). Furthermore, nearly two thirds of the young people who took part in our survey (64\%) said that they were interested in the General Election held in May 2010 (only $14 \%$ had no interest at all). This represents a significant positive shift in engagement since the 2002 study when only $48 \%$ signalled such interest. We also found that a small majority (54\%) considered that they would discuss politics with friends and family in the future, the same proportion as had reported as such in 2002. Taken together, these results seem to run counter to popular thinking that young people are dismissive of political matters. Indeed, the current generation of 18 year olds seem to have more interest in politics and in elections than the cohort of young people who took part in our 2002 study.

\footnotetext{
${ }^{3}$ This study was based on a nationwide survey of 70518 year old attainers conducted in 2002.
} 
As a further indicator of their level of political engagement, we asked an open question designed to identify the single most important issue to them at the moment. A surprisingly high $90 \%$ of young people in the survey mentioned an issue in response to this question. The responses were generally quite detailed and sophisticated, demonstrating a particular engagement with political and current affairs. Figure 1 indicates that they have a very clear youth-oriented agenda, expressing anxiety about their immediate educational and employment prospects. Nearly a third of our sample (31\%) prioritised concerns over the future of higher education and of how young people might survive their university careers (higher education tuition fees - 18\%; student debt $8 \%$; cuts in education - $5 \%$ ). An equal number of young people $(32 \%)$ were concerned about employment- and finance-related issues (job prospects for young people - $12 \%$; the economy/ recession - 12\%; unemployment and factory closures - 4\%; finances/ money - 4\%). The remaining group of young people prioritised a considerably broader agenda, which included race relations and immigration (4\%), the way that the country is governed (3\%), government spending cuts $(3 \%)$, taxation $(2 \%)$, health care $(2 \%)$, and defence, foreign affairs and terrorism (2\%). A further $10 \%$ mentioned other issues. These results seem to contradict the conventional view that young people take little interest in political affairs.

\section{Figure 1: Issues of Most Concern}

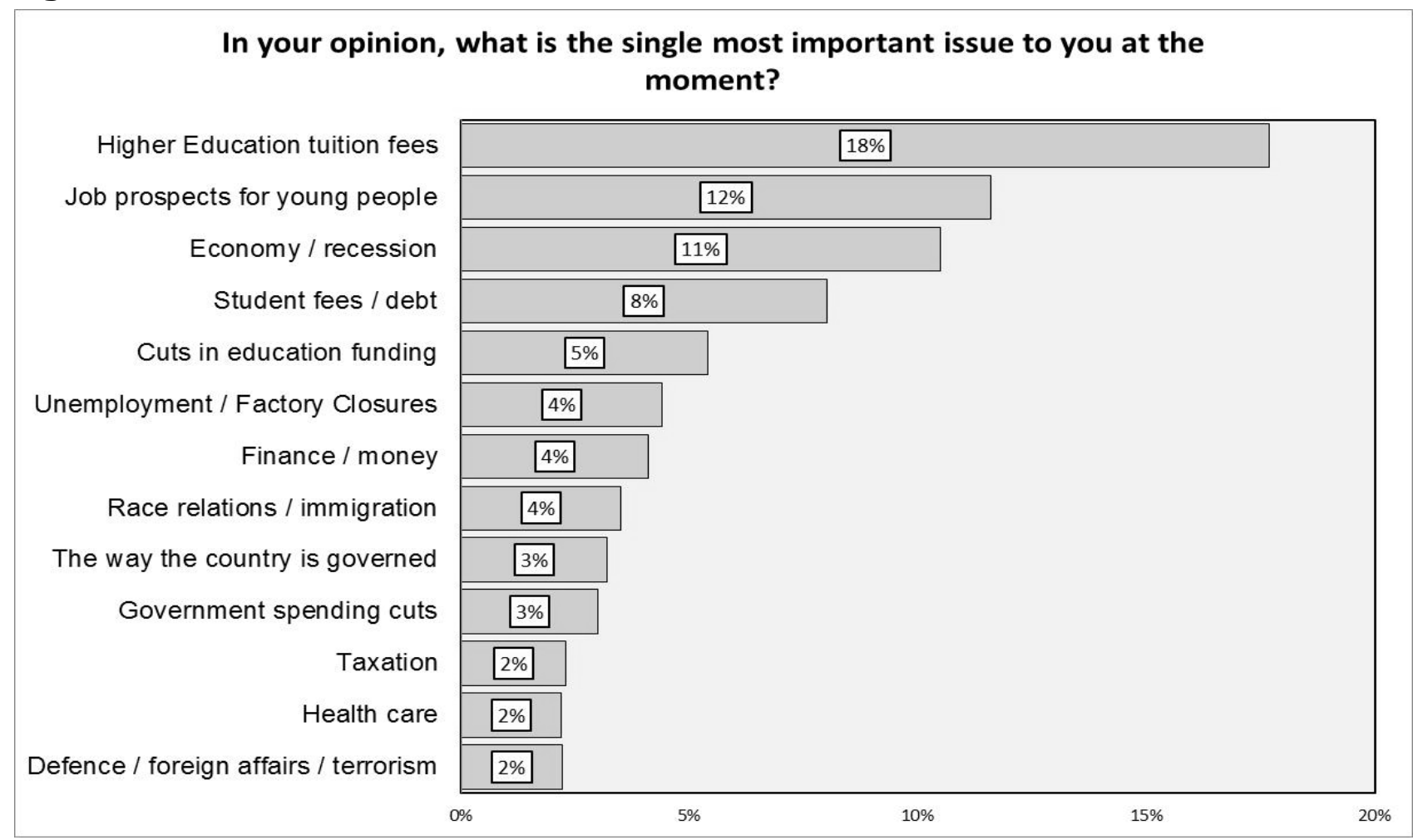

\section{Understanding and knowledge of politics}

Despite young people's continuing interest in politics, the data from the 2011 study broadly reflect the messages from the 2002 youth cohort that a large number of young people continue to lack confidence that they have as much knowledge or understanding of government and politics as they would like. The larger group of young people (52\%) seemed secure in their knowledge of political parties when it comes to deciding how to vote at election times, although a sizeable minority $(46 \%)$ claimed that they do not. Interestingly, this represents an almost exact reversal 
from the 2002 study, when the larger group of young people lacked confidence by a margin of $55 \%$ to $45 \%$. However, young people clearly feel less confident of their knowledge and their understanding of politics in general. Half of the young people taking part in the study (47\%) considered that they don't know enough about what is going on in politics in general, and only a quarter (24\%) felt that they did. ${ }^{4}$ This suggests only a marginal reduction in the degree of apprehensiveness amongst young people when compared with members of the predecessor 2002 youth cohort, when the corresponding figures were $53 \%$ and $24 \%$ respectively. A similar number of the respondents (50\%) doubted their understanding of what is going on in government and politics, and only a fifth (19\%) expressed any confidence. Again, these figures suggest that there remains significant hesitancy in the understanding of politics amongst young people today, although this is less marked than was reported by the previous youth cohort in 2002 (55\% to $25 \%)$.

Combining these three questions as a single measure, we found that overall, $55 \%$ lacked confidence about their knowledge and understanding of British politics, with only $36 \%$ having confidence in such matters. The corresponding figures from the 2002 youth cohort study were $60 \%$ and $34 \%$, indicating a marginal upward trajectory in young people's confidence levels. Nonetheless, these data suggest that for whatever reason, the message about British political life and political affairs is not effectively reaching young people.

We also asked two questions designed to tap into the impact that the 2001 introduction of statutory citizenship classes in schools had had on young people's general understanding of politics. ${ }^{5}$ A quarter of our survey participants (25\%) reported that they had taken a GCSE in Citizenship Studies; of these, $63 \%$ claimed that in doing so, their knowledge and understanding had either increased by not very much or indeed by not all. This suggests a relatively marginal positive impact of formal citizenship classes on the knowledge and understanding of the 18 year olds in our study.

\section{Political power and influence}

Results from our survey indicate that young people do not feel that they can influence the decision-making process. Comparing the percentages of those who agreed with those who disagreed on a number of statements concerning this matter, the data reveal that young people in 2011 feel just as powerless, politically, as did the 2002 youth cohort. Thus, only $15 \%$ agreed with the statement that "the government generally treats young people fairly", whilst more than half (52\%) disagreed. This represents a considerable deepening over time of negative perceptions of the government's approach to young people (with corresponding figures reported in the 2002 survey of $23 \%$ and $42 \%$ respectively). Interestingly, substantially more (69\%) agreed with the sceptical assertion that "there is a big gap between what young people expect out of life and what we actually get", and only a small fraction (6\%) disagreed. This represents a widening since 2002

\footnotetext{
${ }^{4}$ Those who responded "Neither Agreed Nor Disagreed" we define as waverers, and are excluded from these and subsequent analyses of the data so that we can more easily compare the responses of those who hold directional views.

5 These questions were not asked in 2002.
} 
of the distance between those feeling disenfranchised (64\%) and those not (12\%). By a margin of $51 \%$ to $15 \%$, the greater number of today's cohort of young people agreed, rather than disagreed that "young people like me have no say in what the government does". This compares with a similar (albeit slightly larger) gap recorded in the 2002 study when the corresponding figures were $62 \%$ and $21 \%$ respectively.

The 2011 youth cohort clearly feels that "there aren't enough opportunities for young people like me to influence political parties". Although the distance between those who agreed (61\%) and those who disagreed (7\%) with this statement is smaller than it was for the 2002 cohort $(71 \%: 7 \%)$, it remains a considerable one. The survey results also reveal that by an overwhelmingly large majority, most respondents considered that they had little or no influence on "the decisions that are made on (their) behalf by the government and politicians" $(61 \%)$. This compares with only $6 \%$ who felt that they had any influence at all. The corresponding figures for 2002 ( $82 \%$ and $3 \%$ ), suggest a decline in this fatalistic outlook, but nonetheless, there remains a significant degree of pessimism amongst today's youth generation about whether they can help shape and have impact on politics and political affairs.

By combining the results from several related questions, we were able to create an index that demonstrated that only $13 \%$ considered that there existed meaningful opportunities open to them to influence the political scene, while six times as many young people (75\%) denied having access to any such opportunities. This margin of difference $(62 \%)$ is somewhat less than identified in 2002, when the corresponding figures were $12 \%$ and $84 \%$ respectively (with a margin of difference of $72 \%$ ). However, it nonetheless implies that today's generation of 18 year olds remain almost as doubtful about their abilities to gain access and influence over the political process as did their predecessors a decade earlier.

Table 1 summarises the responses to a series of questions concerning young people's evaluation of those methods of political activity that are actually open to them. Interestingly, the data reveal that they consider that these formal methods of political activity are effective in terms of influencing government. This indicates perhaps that they have some faith in the democratic process. When considered alongside the findings noted above (that this 2011 youth cohort feels that the political system remains relatively closed to them), we might conclude that despite feelings of general political powerlessness, young people do appear to have faith in the democratic process itself, and are generally supportive of the notion of elections - the key means open for people to formally participate in politics.

\section{Confidence in the Democratic Process}

The data reveal that more young people said they were satisfied (48\%) than were dissatisfied (32\%) with the way democracy works (although $20 \%$ stated that they were "Not sure"). This represents an increase in the satisfaction levels recorded in the 2002 cohort study. ${ }^{6}$ Combining

\footnotetext{
6 However, It should be noted that in the 2002 study, a different scale was used; there, a 5-point Likert scale was deployed that included a mid-point ("Neither Satisfied Nor Dissatisfied" - 28\%). Excluding this
} 
a number of survey questions into a single index of attitudes to elections, we find that half ( $48 \%$ ) believe in the electoral process, against $37 \%$ who hold more sceptical views. This represents a slight decrease since the 2002 study in the gap between "election-supporters" and "electionsceptics", when the former group outnumbered the latter by a margin of $51 \%$ to $35 \%$.

Table 1: Political activity (\%)

\begin{tabular}{|l|l|l|}
\hline $\begin{array}{l}\text { How effective do you think... (is) for } \\
\text { influencing government? }\end{array}$ & Effective & $\begin{array}{l}\text { Not } \\
\text { effective }\end{array}$ \\
\hline Voting in a general election & 61 & 28 \\
\hline Voting in a local election & 53 & 36 \\
\hline Being a member of a political party & 46 & 37 \\
\hline
\end{tabular}

Table 2 reports the extent to which the 18 year olds in our 2011 survey either agree or disagree with a series of questions about elections, and compares this with findings from the 2002 cohort (figures in brackets). Examination of the individual items broadly indicates that young people do have a general attachment to, and confidence in, the democratic process, and they are typically more positive about elections than were the 2002 cohort. They appear to have an appreciation of civic duty, and also to feel a sense of satisfaction now that they have gained the right to vote. The data seem to indicate that this youth cohort, like their predecessors from 2002, consider that elections do matter in terms of forcing politicians to listen to and engage in talk with voters, and that they keep politicians broadly accountable.

Interestingly, there is a significant reversal of the findings from 2002, when that previous youth cohort were considerably more likely to disagree $(44 \%)$ than agree $(28 \%)$ that by voting they could really help to change the way that Britain is governed. In contrast, the current youth cohort was more likely to agree than disagree with this statement, perhaps reflecting that at the 2010 General Election, the parties did pay greater attention to issues such as Higher Education tuition fees. Nonetheless, only a third (36\%) of them expressed such a positive view, and the gap when measured against the dissenters (29\%), was only $7 \%$. This perhaps suggests only tentative support for the idea that elections can have a real and meaningful impact on government.

Furthermore, the 18 year olds from this current cohort also recognise that elections as a method of democratic participation are limited, and they are broadly sceptical that the outcomes from such democratic contests are positive. A majority (57\%) claimed that although elections allow voters to express their opinions, they don't really change anything. Only $15 \%$ dissented from this sceptical statement. The corresponding figures in 2002 were $60 \%$ and $22 \%$ respectively. Perhaps not surprisingly therefore, there is a noticeable gap between those who would only vote

point (and those responding "Not Sure"), the corresponding figures for those who were satisfied against those who were dissatisfied were $31 \%$ and $26 \%$. 
in an election if they cared who won (40\%) and those who disagreed with that particular view (27\%). The 2002 cohort figures were $47 \%$ and $30 \%$ respectively, signalling that there has been a marginal fall in the gap between election sceptics and election-supporters, from $17 \%$ to $13 \%$ over time. This suggests that young people remain serious and discerning (sceptical) observerparticipants of the electoral process, rather than merely uninterested and apathetic onlookers.

Table 2: Support for the Democratic Process (\%)

\begin{tabular}{|l|l|l|}
\hline & $\begin{array}{l}\text { Agree } \\
(\mathbf{2 0 0 2})\end{array}$ & $\begin{array}{l}\text { Disagree } \\
(\mathbf{2 0 0 2})^{7}\end{array}$ \\
\hline I feel/would feel a sense of satisfaction when I vote/ if I voted. & 52 & 14 \\
$(44)$ & $(22)$ \\
\hline $\begin{array}{l}\text { I would be seriously neglecting my duty as a citizen if I didn't } \\
\text { vote. }\end{array}$ & 45 & 22 \\
$(43)$ & $(32)$ \\
\hline $\begin{array}{l}\text { Having regular elections forces politicians to listen carefully to } \\
\text { public opinion. }\end{array}$ & 50 & 20 \\
$(51)$ & $(27)$ \\
\hline $\begin{array}{l}\text { Elections give voters an opportunity to tell politicians what } \\
\text { they think is really important. }\end{array}$ & 53 & 18 \\
\hline $\begin{array}{l}\text { Elections help to keep politicians accountable for the promises } \\
\text { they make. }\end{array}$ & $434)$ & $(32)$ \\
\hline $\begin{array}{l}\text { By voting/ if I voted, I feel as if I can/ could really help to } \\
\text { change the way that Britain is governed }\end{array}$ & 36 \\
\hline
\end{tabular}

Particularly revealing, is that whereas a significant gap was identified in the 2002 study between those who agreed (24\%) and those who disagreed (49\%) with the sceptical statement that "All things considered, most elections are just a big waste of time and money", there are almost as many election doubters within the current 2011 cohort (32\%) as there are election believers (33\%). This represents a significant fall in the election supporter/sceptic gap, from $25 \%$ in 2002 to only $1 \%$ today. This finding adds weight to the conclusion that 18 year olds today are broadly in support of the principle and system of elections and of the democratic process, but that they lack confidence in the actual election outcomes.

Notwithstanding their doubt over the value of elections in facilitating meaningful change, over two thirds (69\%) of our sample of young people claimed to have participated at the 2010 General Election - their first occasion to cast a vote. Although we do not know the precise figures for the proportion of 18 year olds who voted at that contest, this survey response probably overestimates the number of those that did so, and compares with $44 \%$ of the broader $18-24$ year old age group (Ipsos MORI, 2010). ${ }^{8}$ Of the "voters", by far and away the largest group (55\%) were motivated to cast their ballot on the basis of party policies. Interestingly, as few people voted in line with family tradition (7\%) as had cast their vote in support of a local candidate

\footnotetext{
72011 results reported, with results from the 2002 survey reported in brackets here and in subsequent tables.

8 The over-estimation of voting recall is not uncommon in surveys of this nature. For instance, the 2010 British Election Study reports that $90 \%$ of respondents to the post-election Internet survey claimed to have voted, compared to the actual turnout of $65 \%$ (Clarke et al., 2010).
} 
$(6 \%)$, or for a particular party leader $(7 \%)$ or had voted against one of the other parties or candidates $(6 \%)$. A similar proportion of this cohort of young people had really preferred another party but considered that it stood no chance of winning in their constituency (6\%). Finally, a small group ( $3 \%$ ) claimed that they had followed the advice of their friends.

Respondents were then asked how likely it was that they might take part in various types of political activity over the next few years. As Table 3 indicates, this 2011 youth cohort support the idea of elections, and in principle, large numbers claim that they would consider voting at future contests. Indeed, they are more likely to profess an intention to vote in future local and European elections than were those questioned as part of the 2002 cohort study; they are also less likely to report that they intend to abstain.

Table 3: Future voting intentions (\%)

\begin{tabular}{|c|c|c|}
\hline & $\begin{array}{l}\text { Likely } \\
\text { (2002) }\end{array}$ & $\begin{array}{l}\text { Unlikely } \\
\text { (2002) }\end{array}$ \\
\hline Vote in the next UK general election & $\begin{array}{l}64 \\
(67)\end{array}$ & $\begin{array}{l}16 \\
(16)\end{array}$ \\
\hline Vote in the next local council election & $\begin{array}{l}53 \\
(46)\end{array}$ & $\begin{array}{l}21 \\
(32)\end{array}$ \\
\hline $\begin{array}{l}\text { Vote in the next election for the European } \\
\text { Parliament }\end{array}$ & $\begin{array}{l}42 \\
(35)\end{array}$ & $\begin{array}{l}28 \\
(37)\end{array}$ \\
\hline Vote in the next Scottish Parliament election & $\begin{array}{l}66 \\
(N / A)\end{array}$ & $\begin{array}{l}14 \\
(N / A)\end{array}$ \\
\hline Vote in the next Welsh Assembly election & $\begin{array}{l}56 \\
(\mathrm{~N} / \mathrm{A}) \\
\end{array}$ & $\begin{array}{l}13 \\
(\mathrm{~N} / \mathrm{A})\end{array}$ \\
\hline Vote in the next London Mayoral election & $\begin{array}{l}56 \\
(N / A)\end{array}$ & $\begin{array}{l}24 \\
(N / A)\end{array}$ \\
\hline
\end{tabular}

We then asked a series of questions concerning respondents' likelihood of offering formal support to the political parties. The results suggest that as was the case with 18 year olds from the 2002 study, today's generation of young people cannot bring themselves to actually support the main political parties in practice. Only $6 \%$ reported that they would be likely in the future to give money to any of the political parties, and $76 \%$ would not. A similarly small fraction of young people stated that they would actually be prepared to work for a political party or a candidate in an election campaign ( $8 \%)$, and the overwhelming majority (70\%) reported that they would be unlikely to ever do so. Finally, only $22 \%$ of this particular youth cohort claimed that they would ever consider trying to convince someone else how to vote (50\% would be unlikely to do so). These figures broadly reflect the findings from the 2002 cohort of 18 year olds.

\section{Trust in political parties and professional politicians}

Responses to a series of questions about the political parties and professional politicians provide the very clear view that the 2011 cohort continues to hold a deep antipathy towards, and distrust 
in, these political players - and that these feelings are as strongly felt today as they were by the 2002 predecessor cohort.

When asked what they think about the ability of the political parties to find suitable people to run for parliament, only $22 \%$ considered that they do a good job in this process; a slightly larger group (29\%) felt that this is not the case, while the dominant group (49\%) was uncertain. ${ }^{9}$ This finding suggests a somewhat less than positive endorsement of the political parties and professional politicians. What is certain is that young people continue to have a relatively low level of party identification (35\%) compared to those who reported that they do not connect with any particular political party (57\%). These findings compare with a slightly smaller level of party identification ( $28 \%$ ) reported by the 2002 cohort ( $59 \%$ without any such identification).

Furthermore, other findings within the study support the view that young people today have little trust or confidence in the political parties and professional politicians. Our results tend to reinforce those from a number of previous studies that show an apparent disconnection from party politics - in many cases this is very noticeable indeed. We created an index based on several questions from the survey which summarises young people's perceptions of political parties and professional politicians. Only $17 \%$ of this particular cohort of young people were positively disposed towards these political players, whereas the vast majority $(81 \%)$ held a negative view of them. These figures are broadly comparable with those recorded for the 2002 cohort ( $13 \%$ and $85 \%$ respectively).

A detailed examination of the specific views that young people have of politicians and the political parties is revealed in Table 4. These data indicate that young people appear to hold deeply sceptical views of these political players and of the way that they conduct their activities - and that the strength and direction of these views is not noticeably different from those offered by the predecessor youth cohort from 2002. This suggests that youth distrust of parties has not appreciably diminished with time.

Furthermore, the majority of this 2011 youth cohort considers that the political parties are remote, and do not seek to positively connect with young people or their concerns - beyond trying to win their votes. By a considerable margin ( $51 \%$ to $12 \%)$, this generation tended to disagree that political parties do a good job of listening to young people's concerns and then responding to them positively. This compares with a somewhat more sceptical view offered by the 2002 cohort (63\% to 7\%), but nonetheless still suggests a considerable lack of trust by young people in these political players. That finding perhaps reflects another that young people are of the opinion that governments don't really care what young people like themselves think; while $54 \%$ agreed with this statement, only $14 \%$ were in disagreement. This represents an increase in young people's scepticism levels over those recorded by their predecessors in 2002 when the equivalent figures were $39 \%$ and $26 \%$ respectively. Finally, a significant majority of young people also considered that those elected to Parliament soon lose touch with people $(62 \%)$, and only a fraction dissented (6\%) from this doubting view. These findings are broadly

\footnotetext{
9 This question was not asked in 2002.
} 
in line (if even more negative) with those expressed by the 2002 cohort ( $59 \%$ to $12 \%$ ). The findings outlined above are perhaps aptly summarised in the general observation offered by young people, that parties are only interested in people's votes, not in their opinions. Exactly the same proportions of young people in 2011 responded as did their 2002 predecessors, with two thirds in agreement (65\%) and only $8 \%$ dissenting (14\% in 2002).

Table 4: Perception of political parties and professional politicians (\%)

\begin{tabular}{|c|c|c|}
\hline & $\begin{array}{l}\text { Agree } \\
(2002)\end{array}$ & $\begin{array}{l}\text { Disagree } \\
(2002)\end{array}$ \\
\hline $\begin{array}{l}\text { Political parties are effective organisations for changing the } \\
\text { lives of people for the better }\end{array}$ & $\begin{array}{l}21 \\
(N / A)\end{array}$ & $\begin{array}{l}31 \\
(N / A)\end{array}$ \\
\hline $\begin{array}{l}\text { There is often a big difference between what a party promises } \\
\text { it will do and what it does when it wins an election. }\end{array}$ & $\begin{array}{l}75 \\
(87)\end{array}$ & $\begin{array}{l}3 \\
(3)\end{array}$ \\
\hline $\begin{array}{l}\text { Political parties are more interested in winning elections than } \\
\text { in governing afterwards. }\end{array}$ & $\begin{array}{l}65 \\
(69)\end{array}$ & $\begin{array}{l}9 \\
(13)\end{array}$ \\
\hline Political parties do more to divide the country than unite it. & $\begin{array}{l}47 \\
(41)\end{array}$ & $\begin{array}{l}12 \\
(24)\end{array}$ \\
\hline $\begin{array}{l}\text { My Member of Parliament tries hard to look after the interests } \\
\text { of people in my constituency }\end{array}$ & $\begin{array}{l}24 \\
(N / A)\end{array}$ & $\begin{array}{l}17 \\
(\mathrm{~N} / \mathrm{A})\end{array}$ \\
\hline $\begin{array}{l}\text { In elections, political parties don't tell people about the really } \\
\text { important problems facing the country. }\end{array}$ & $\begin{array}{l}48 \\
(50)\end{array}$ & $\begin{array}{l}16 \\
(21)\end{array}$ \\
\hline $\begin{array}{l}\text { Political parties aren't interested in the same issues that } \\
\text { concern young people. }\end{array}$ & $\begin{array}{l}64 \\
(59)\end{array}$ & $\begin{array}{l}7 \\
(10)\end{array}$ \\
\hline $\begin{array}{l}\text { The main political parties in Britain don't offer voters real } \\
\text { choices in elections because their policies are pretty much all } \\
\text { the same }\end{array}$ & $\begin{array}{l}40 \\
(48)\end{array}$ & $\begin{array}{l}18 \\
(22)\end{array}$ \\
\hline
\end{tabular}

Perhaps not surprisingly given the findings above, large majorities of young people report that they lack trust in democratic institutions as well as those individuals and agencies that inhabit them. ${ }^{10}$ There seems to be a somewhat varied view with respect to democratic institutions. Only $15 \%$ said that they considered that, on balance, UK governments (past and present) tend to be honest and trustworthy, while the view of the overwhelming majority (66\%) was that they were not. We separated out the views of those young people living in Scotland and those in Wales, and analyses reveal that the majority living in each of these countries are broadly positive about their own democratic institutions. Fully $43 \%$ of 18 year olds living in Scotland considered the Scottish Parliament to be honest and trustworthy (32\% not), while a third of young people living in Wales (36\%) felt positive about the Welsh Assembly (19\% not). We then asked respondents to indicate the degree of trust that they invested in the political parties and in politicians. As Table 5 indicates, young people in Britain are deeply distrustful of these political players who are charged with conducting formal politics on their behalf. Interestingly, they are slightly more sceptical of professional politicians than they are of the political parties, and this may partly reflect the impact of the UK parliamentary expenses scandal which first gained (enduring) prominence as a political issue in May 2009.

10 These questions were not asked in 2002. 
Table 5: Trust in parties and professional politicians (\%)

\begin{tabular}{|l|c|c|}
\hline $\begin{array}{l}\text { Using a scale from 1 - 5 where 1 means no } \\
\text { trust and } 5 \text { means a great deal of trust, how } \\
\text { much do you trust [ . . ] in general? }\end{array}$ & $\begin{array}{l}\text { Some or a great } \\
\text { deal of trust }\end{array}$ & $\begin{array}{l}\text { Little or no } \\
\text { trust }\end{array}$ \\
\hline Political parties & 8 & 57 \\
\hline Politicians & 6 & 63 \\
\hline
\end{tabular}

\section{Re-connecting young people: The challenge for political parties}

We asked an open question in order to find out what might be done to reverse young people's distrust in, and antipathy towards, the political parties and professional politicians. Figure 2 categorises these open responses, and confirms that there is a widely held belief within this 2011 cohort that the political parties should do more to directly connect with young people, by talking with $(7 \%)$ and listening to them (16\%), by visiting schools, colleges and universities $(10 \%)$, and by using innovative connection methods such as questionnaires and surveys $(10 \%)$, holding "Question Time"-style forums, conferences and meetings (7\%), and using the Internet, social networking methods (such as Facebook and Twitter) and email (8\%). ${ }^{11}$ In addition, there is a similarly clear message that political parties and professional politicians should then action young people's concerns. In particular, by adopting a more young person-centred approach and focus in their political work $(6 \%)$, by involving young people more in doing so $(4 \%)$, by championing the issues and concerns of young people (10\%), and by delivering on their promises $(5 \%)$.

Clearly, these data suggest that for young people to be brought back into the democratic fold, political parties will need to reflect seriously on how they approach them in the future. As we have seen, young people do have an interest in politics, but specifically in a politics that respects their intelligence and represents their views; they want to be taken seriously. The young people in our cohort study have given the clear message that if political parties begin to better understand the youth agenda, the support is there to be gained, and this support could ultimately transform into votes. The key principles of gaining trust, communicating with young people, and entering into a youth discourse are all interlinked. Parties need to tackle the communication problem first, as only then can an understanding of the youth agenda begin to develop. Should they do this, there might then follow a shift in young people's perceptions of the parties, an increase of their trust in the political classes, and an overall strengthening of youth engagement with the political and democratic processes.

11 Respondents had the opportunity to mention more than one means of connecting if they wished. Percentages reported represent the proportion of total number of respondents to this question, rather than of the total number of responses given. 


\section{Figure 2: The challenge for political parties}

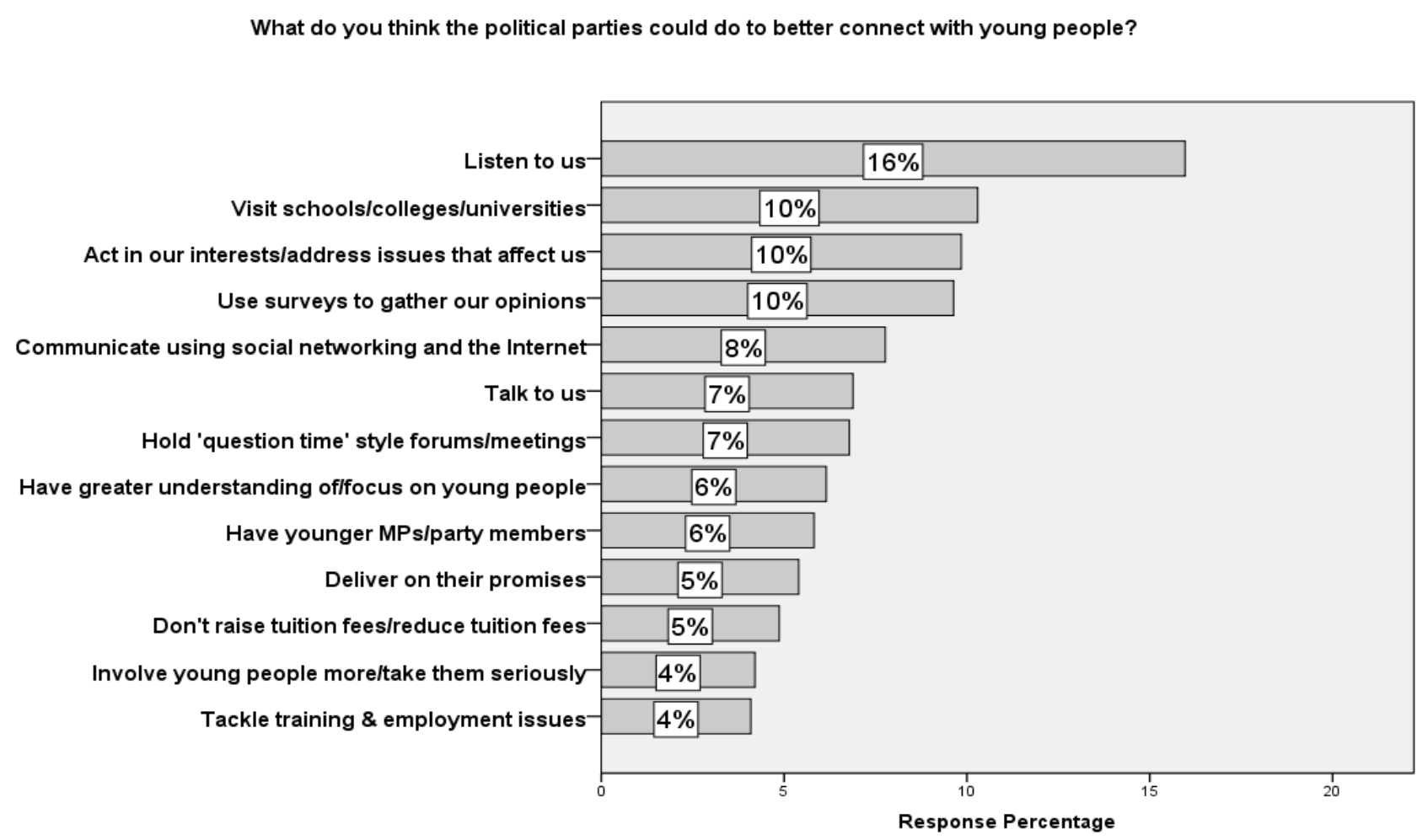

\section{CONCLUSION}

Contrary to the common stereotype of a politically apathetic generation, all the evidence from our study points towards a group of young people who are interested in political affairs. Like their predecessors in 2002, young people in 2011 have an interest in a range of political issues, and have a clear youth agenda. They are also supporters of the idea of representative democracy. Although they are doubtful that the outcomes from elections are positive or can help to bring about effective change in the way that society is governed, they certainly hold an attachment to the general democratic process, and support the broad principle of elections. They do therefore have a civic orientation. Indeed, they would like to play a more active role in the democratic process in the future.

However, they also consider that the political system remains relatively closed to young people like themselves, and believe that there are few opportunities afforded to them to intervene effectively within the political process to help shape the way that decisions are made. Consequently, today's generation of young people feel relatively powerless, politically - just as did their predecessors a decade previously.

Furthermore, despite their general support for the democratic process, young people's recent experience of their first general election in 2010 has left them feeling somewhat disheartened and frustrated. Indeed, our study has revealed a considerable aversion to formal, professional politics which is as deep as it was for young people in 2002. Politicians are clearly regarded as a group with self-serving interests, in whom attainers today have as little trust as did their predecessor cohort a decade earlier. These findings add weight to Norris's point that '[d]uring the last decade, a few established democracies (notably the UK and Portugal) experienced a 
rising tide of mistrust about government institutions, which should raise concern in these particular countries' $(2011,58)$.

The conclusion that we must draw from these findings, is that young people feel disenchanted by their recent experiences of formal politics, and remain relatively disengaged from the political process and from democratic institutions and players. This is despite the considerable political reforms that governments have introduced over the course of the last decade that were ostensibly designed to provide citizens with greater access to the centres of political power, and to increase their influence over the political process. Increased devolution and localisation of power, along with citizenship education were intended to bring politics closer to citizens and to increase levels of proficiency. The new coalition government certainly looks set to intensify reforms designed to empower on a local level, yet the future of citizenship education hangs in the balance. Stoker (2011) recognises the importance of all of these reforms in tackling causes of disengagement, but also proposes further solutions which are reflected in our findings. These centre around the perceived ability of elected representatives to perform effectively and to tackle the issues of greatest pertinence to citizens.

The evidence from this study indicates that today's generation of young people are not appreciably different from their youth predecessors of 2002. This would seem to suggest that the disconnection from the political process that was apparent in the aftermath of the 2001 General Election was not merely a particular and one-off cohort effect, but rather a point in a process of continuing youth disengagement that shows no signs of diminishing a decade later. For politicians and policy-makers, this state of affairs continues to leave them nervous and of the opinion that young people may carry their political scepticism with them into later life. The long-term consequences of such a scenario are that in the future, they would replace the somewhat more politically-engaged older adult generation, and that this would ultimately call into question the legitimacy of the formal political process and of democratic institutions. If young people are to be re-connected to the formal political process, then there is considerable scope for these same political actors to intervene in ways that might help young people to see the potential value in doing so. Certainly, young people would welcome an approach from the political parties and from individual politicians that was direct and clearly prompted by a desire to genuinely articulate and then champion the views and interests of young people. At present, young people feel as if professional politicians are rather cynical in their dealings with ordinary citizens. There is therefore some serious public relations work needed in order for politicians to overcome this distrust and to demonstrate that their intentions in reaching out to connect with people - and young people in particular - are motivated by a sincere and transparent concern to listen to their voices and then act upon them accordingly.

\section{REFERENCES}

Bennett, W.L. (ed) (2008) Civic Life Online: Learning How Digital Media Can Engage Youth. Cambridge, MA: MIT Press.

Butler, D., and Kavanagh, D. (1997) The British General Election of 1997. Hampshire: Macmillan Press. 
Chang, L., and Krosnick, J.A. (2009) 'National Surveys via RDD Telephone Interviewing Versus the Internet: Comparing Representativeness and Response Quality', Public Opinion Quarterly, 73, (4), 641-678.

Clarke, H., Sanders, D., Stewart, M., Whiteley, P. (2010) Measuring Turnout Who Voted in 2010?, http://eprints.ncrm.ac.uk/1586/1/whiteley measuring turnout.ppt. Accessed 31 October 2011.

Clarke, H.D., Sanders, D., Stewart, M.C., and Whiteley, P. (2004) Political Choice in Britain. Oxford: Oxford University Press.

Couper, M. P. (2000) 'Web Surveys: A Review of Issues and Approaches'. Public Opinion Quarterly, 64, (4), 464-494.

Electoral Commission and the Hansard Society (2006) An Audit of Political Engagement 3. London: The Electoral Commission and the Hansard Society.

Electoral Commission and the Hansard Society (2007) An Audit of Political Engagement 4. London: The Electoral Commission and the Hansard Society.

Electoral Commission (2005). Election 2005: Turnout, How Many, Who and Why? London: The Electoral Commission.

Franklin, B. (2004) Packaging Politics: Political Communications in Britain's Media Democracy. London: Arnold, Second Edition.

Henn, M., and Weinstein, M. (2003) First-time Voters' Attitudes Towards Party Politics in Britain, Project reference R000223598. Swindon: Economic and Social Research Council.

Henn, M., Weinstein, M., and Forrest, S. (2005) 'Uninterested youth? Young people's attitudes towards party politics in Britain', Political Studies, 53, (3), 556-578.

Henn, M., and Weinstein, M. (2006) 'Young People and Political (In)Activism: Why Don't Young People Vote?', Policy and Politics, 34, (3), 517-34.

Hewson, C., Yule, P., Laurent, D., Vogel, C. (2002) Internet Research Methods : A Practical Guide for the Behavioural and Social Sciences. London: Sage.

Ipsos MORI (2010) 'How Britain Voted in 2010'. Available at http://www.ipsosmori.com/researchpublications/researcharchive/poll.aspx?oItemId=2613\&view $=$ wide (last accessed 16 September 2011).

Jowell, R., and Park, A. (1998) Young People, Politics and Citizenship: A Disengaged Generation? London: Citizenship Foundation.

Kimberlee, R. (2002) 'Why Don't Young People Vote at General Elections?' Journal of Youth Studies, 5, (1), 85-97.

Loader, B.D. (ed) (2007) Young Citizens in the Digital Age: Political Engagement, Young People and New Media. London: Routledge.

Matthews, H. (2001) 'Citizenship, Youth Councils, and Young People's Participation'. Journal of Youth Studies, 4, (3), 299-318

Ministry of Justice (2007) 'The Governance of Britain'. Available at: http://www.officialdocuments.gov.uk/document/cm71/7170/7170.pdf (last accessed 16 September 2011).

Norris, P. (2003). 'Young People and Political Activism: From the Politics of Loyalties to the Politics of Choice?', paper presented at the Council of Europe Symposium, Young People and Democratic Institutions: From Disillusionment to Participation', Strasbourg, 27-28 November. Norris, P., (2011) Democratic Deficit: Critical Citizens Revisited. Cambridge: Cambridge University Press. 
Office for National Statistics (2010) 'Internet Access 2010: Households and Individuals'. Available online at http://www.ons.gov.uk/ons/rel/rdit2/internet-access---households-andindividuals/historical-internet-access/9-2-million-uk-adults-have-never-used-the-interne.pdf (last accessed 16 September 2011).

Park, A. (1995) 'Teenagers and their Politics', in Jowell, R. Curtice, J. Brook, L. and Witherspoon, S. (eds), British Social Attitudes: The $12^{\text {th }}$ Report, Aldershot: Dartmouth

Pattie, C., Seyd, P. and Whiteley, P., 2004. Citizenship in Britain: Values, Participation and Democracy. Cambridge: Cambridge University Press.

Quintelier, E. (2007) 'Differences in Participation Between Young and Old People'. Contemporary Politics, 13, (2), 165-180.

Roker, D. and Eden, K. (2002) '...Doing Something': Young People as Social Actors. Leicester: National Youth Agency

Russell, A., Fieldhouse, E., Purdam, K. and Kalra, V. (2002) Voter Engagement And Young People. London: The Electoral Commission.

Sloam, J. (2007) 'Rebooting Democracy: Youth Participation in Politics in The UK', Parliamentary Affairs, 60, (4), 548-567.

Stoker, G. (2011) 'Anti-Politics in Britain', in Heffernan, R., Cowley, P., and Hay, C. (eds), Developments in British Politics Nine. Basingstoke: Palgrave Macmillan.

Swaddle, K., and Heath, A. (1992) 'Official and Reported Turnout in the British General Election of 1987', in Denver, D. and Hands, G. (eds), Issues and Controversies in British Electoral Behaviour. London: Harvester Wheatsheaf.

Tilley, J. (2003) 'Party Identification in Britain: Does Length of Time in the Electorate Affect Strength of Partisanship?' British Journal of Political Science, 33, (2), 332-344.

Wattenburg, M. (2002) Where Have All the Voters Gone? London: Harvard University Press.

Whiteley, P. and Seyd, P. (2002) High-intensity Participation: The Dynamics of Party Activism in Britain. Ann Arbor: University of Michigan Press.

Wring, D. and Ward, S. (2010) 'The Media and the 2010 Campaign: the Televised Election?', Parliamentary Affairs, 63, 802-817

\section{Funding}

This work was supported by the Economic and Social Research Council [RES-000-22-4450].

\section{Acknowledgements}

We would like to thank: Paul Carroll and Sarah Pope at Ipsos-MORI, both for their preparation of the data and for their general contribution to the project; the anonymous referees for their very useful feedback on the initial draft. 